\title{
THE POSSIBILITIES OF INTERPRETIVE LIBERALISM
}

\section{MARK TUSHNET*}

The author presents a survey of normative interpretive approaches to liberalism. He begins with a dicussion of the attractions of, and our demands on, an interpretive approach to political theory. It is suggested that interpretive approaches to liberalism run up against many difficulties. The reformist interpretive approach is examined and some general problems with the "republican tradition" version of interpretive normative theory are illustrated. A second interpretive approach which accepts society's practices but also draws on systematic political philosophy is discussed but the author remains sceptical of its merits. A related interpetive strategy for purifying existing practices is to contrast them in an historical sense and examine the "overlapping consensus". There are objections to this as well. The author concludes that none of the strategies surveyed give precise enough guidance in resolving current controversies in liberalism and reflects on the result of this finding.
L'auteur présente plusieurs méthodes d'interprétation normative du libéralisme. Il commence par une discussion de l'attrait et des impératifs motivant de telles démarches, et suggère qu'elles se heurtent pourtant a de nombreuses difficultes. Il examine l'approche reformiste et présente quelques problemes généraux soulevés par cette version de la "tradition républicaine". L'auteur parle également d' une seconde approche qui accepte les pratiques de la société tout en s'inspirant d'une philosophie politique systématique, mais il se dit sceptique quant à ses mérites. Une stratégie connexe visant à purifier les pratiques existantes les oppose dans un cadre historique et examine le 'chevauchement des consensus'. L'auteur exprime ses objections et conclut qu'aucune des stratégies présentées ne permet de résoudre les controverses actuelles en matière de libéralisme. Il fait part des réflexions que lui inspire cette constatation.

This essay explores the proposition that the task of normative political theory is to interpret a political culture to itself. At the outset I must insert a disclaimer: As is appropriate for the venue, this is an essay on philosophical topics. Yet, I am not trained as a philosopher and have become acutely uncomfortable as I have ventured more deeply into the jurisprudential terrain. I acknowledge that probably all law professors "do" jurisprudence in their work, and that it must be all to the good that we become aware of that. I suspect, however, that at best this means that we are like Moliere's Monsieur Jourdain, speaking prose - or jurisprudence - all our lives without knowing it. And, I had thought, one implication of Moliere's observation is that people who speak prose without knowing it probably are speaking bad prose. So too with law professors doing jurisprudence. But, I have committed myself to this project and so, asking that you adopt a principle of charity in interpretation, I proceed.'

Professor at Georgetown University Law Center. A somewhat shorter version of this essay was presented as the Second McDonald Lecture of the Centre for Constitutional Studies at the University of Alberta. I am grateful to the Centre and its director, David Schneiderman, for their hospitality and for giving me the opportunity to develop my thoughts on these questions. The initial version of this essay was presented at a conference at Williams College on November 4, 1988, where 1 received extremely helpful comments from David Weissbord.

1. Alternatively, the essay could be read as a document indicating how an amateur has assimilated certain arguments being made by professionals, and thereby showing how professional discourse works its way into the discourse of legal analysis. 
The proposition that the role of normative political theory is to interpret a political culture to itself seems to be at the base of the work of such theorists as Alisdair Mclntyre and Michael Walzer, ${ }^{2}$ who have, however, been more interested in defending the method of interpretive political theory than in offering an interpretive theory for the United States. ${ }^{3}$ In this essay I examine attempts to place contemporary liberalism in the United States on an interpretive base.

I begin with a brief sketch of why interpretive approaches to liberalism have become attractive, which will show why a successful interpretive analysis would be quite important. Then I describe a fundamental problem with interpretive approaches generally, as a preface to the more complete discussion that follows of particular works. That discussion can be read as an effort to explain how the authors I discuss attempt to overcome the fundamental problem I describe.

The general crisis of legitimacy of the liberal state is perhaps the primary impetus for efforts to reconstruct liberal political theory. ${ }^{4}$ The thought appears to be that, were we to have available to us a generally acceptable liberal political theory, we would be able to develop a public discourse that would explain to us why the liberal state deserves our allegiance. There have, of course, been prominent attempts to reconstruct liberal political theory in noninterpretive terms. These attempts are in the direct line of descent from classical liberal theory, in that they attempt to develop principles of the liberal social order to which all rational people would necessarily give assent. Their reliance on context-free standards of rationality makes them noninterpretive. ${ }^{5}$ Yet, it is precisely that absence of concern for context that has led many critics to claim that these reconstructions are unavailing. For example, the prevalent view of John Rawls's work puts it in the noninterpretive line, ${ }^{6}$ and the most telling criticism of his work so viewed is Michael Sandel's argument that Rawls wrongly relies on a notion of the self as unencumbered by any social setting. ${ }^{7}$ If liberalism could be placed on an interpretive base, in contrast, it would honor the commitments we actually have to each other and to the society in which we live. In particular, an interpretive base for liberalism would allow us to preserve at least some of the undeniably attractive features of liberalism, such as its defense of

2. Alisdair MacIntyre, After Virtue: A Study in Moral Theory (Notre Dame: Notre Dame University Press, 1982); Micahel Walzer, Spheres of Justice (New York: Basic Books, 1983). Also see William Sullivan, Reconstructing Public Philosophy (Berkeley: University of Califomia Press, 1982).

See Thomas Spragens, "Liberalism, Republicanism, and Rational Practice" (Address to the Annual Meeting of the American Political Science Association, September 1-4, 1988). ("When it comes to providing a constructive and affirmative philosophical foundation for the communitarian viewpoint. we find rather thin fare").

4. Sullivan, Reconstructing Public Philosophy, supra note 2 at 56.

5. See e.g. Bruce Ackerman, Social Justice in the Liberal State (New Haven: Yale University Press, 1980).

6. For a discussion of Rawls's work seen as an interpretive effort, see text accompanying notes 33-37.

7. Michael Sandel, Liberalism and the Limits of Justice (New York: Cambridge University Press, 1982). 
toleration as a public policy, ${ }^{8}$ its concern for freedom of expression, and its concept that there is a sphere of private activity into which public power ought not intrude. ${ }^{9}$

An interpretive approach to liberalism is attractive, in addition, because such an approach would bring (some versions of) liberal political theory into line with (some versions of) social thought more generally. That is, in recent years interpretive approaches to sociology, language meaning, and the like have become attractive in those disciplines. To the extent that an interpretive approach to liberalism converges with similar approaches in allied disciplines, its foundations might be strengthened. Even more, if an interpretive approach managed to converge with some important noninterpretive approaches, we might think that we had cornered liberalism in a way that made its claims even more powerful.

It is important, however, to specify what one might want out of an interpretive, or indeed any other, approach to political theory. I suggest that an interpretive approach must offer more precise guidance on controverted issues of public policy than the generalities about freedom of expression and equality mentioned earlier. After all, the communitarian critics of liberalism ${ }^{10}$ do not fundamentally challenge these accomplishments of liberalism. They may be somewhat more sympathetic to claims that an internally unified community should be allowed to censor objectionable material than liberals are, and they may be somewhat more sensitive to the risks that imposing universal norms of rights creates to the continued survival of a community. However, it should be noted that even liberals are divided on these issues, ${ }^{11}$ and it is reasonably clear that the generalities I mentioned offer little guidance, even within the liberal tradition, to the resolution of these controversies. What matters, I would think, is the guidance a normative approach offers for the resolution of controversies that have recently arisen or are likely to arise in the future. ${ }^{12}$

We might contrast here an approach that establishes that the regime under which the religious wars of the sixteenth and seventeenth centuries occurred is inconsistent with liberalism, with an approach that establishes that only modern welfare state liberalism is consistent with liberalism. I suggest that the former approach has a certain amount of

8. If not necessarily of tolerance as an individual character trait.

9. This is not to say, of course, that the definitions of the private sphere, for example, offered in common noninterpretive approaches to liberalism would be precisely replicated in every interpretive approach. Indeed, one of the attractions of interpretive approaches is that they offer the possibility of correcting the definitions offered by noninterpretive ones.

For a general discussion of these critics, see Amy Gutmann, "Communitarian Critics of Liberalism" (1985) 14 Phil. \& Pub. Aff. 308.

11. On censorship, see e.g. Cass Sunstein, "Pornography and the First Amendment" [1986] Duke L.J. 589; on threats to community, see e.g. Wisconsin v. Yoder (1972) 406 U.S. 205.

12. See e.g. Roger Smith, Liberalism and American Constitutional Law (Cambridge: Harvard University Press, 1985) at 254-56, proposing reforms in the protection given to entry into professions; John Rawls, "The Basic Liberties and Their Priority" in Sterling McMurrin, ed., Liberty, Equality, and Law (Salt Lake City: University of Utah Press, 1987) at 55-84, discussing principles of free expression. 
historical interest, but because it fails to provide guidance on pressing modern concerns it will not engage our deepest interest. Somewhat more interesting might be an approach that ruled out Stalinism and Naziism as forms of a liberal state, because those are forms of rule that we have experienced in this century. Yet, I believe, even such an approach is not fully engaging because a recrudescence of Stalinism or Naziism is not realistically in prospect in advanced Western societies in the near future. ${ }^{13}$ Finally, an approach that fails to adjudicate between laissez-faire liberalism of the sort associated with the name of Herbert Spencer, and democratic socialism of the sort associated with modern Scandinavian democracies is again unlikely to be fully satisfying, although it may be the best we can expect. As I will argue, the interpretive approaches to liberalism in the field at present seem likely to run up against one or more of these difficulties.

Initially, an interpretive approach to liberalism might seem pointless. Normative political theories usually are reformist in the sense that they attempt to show that at least some aspects of the present operation of the political order need revision in light of theoretical analysis. Yet, if the point of an interpretive theory is to interpret a society to itself, how can such a theory have that reformist quality? ${ }^{14}$ What we are interpreting are the preferences and policies of the actually existing society, and it is difficult to see the way in which we can derive norms from those preferences and policies that call for the reform of the very preferences and policies that are the source of the norms. Before examining several attempts to infuse reformist elements into an interpretive approach, I should note the possibility that an interpretive normative political theory need not have such elements. The idea would be that the interpretation of a society's practices to itself calls for the deployment of a number of stories about those practices, to explain to different people in different ways what those practices are. A normative political theorist might tell a number of these stories, each one prefaced with a statement like, "Well, if you don't see it that way, how about trying it this way?" I would be quite interested in seeing works of this sort, though I confess that I am not entirely sure that they would deserve the label "normative."15

A reformist interpretive approach might take a number of paths. The easiest to understand, perhaps, is one that calls to our attention aspects of our society's practices that we tend to overlook. These aspects are suppressed from consciousness, and the interpretive theorist's task is, like that of the psychoanalyst, to bring them to consciousness so that we can make better sense of what we actually are doing in our society and thereby improve the functioning of our institutions, whose operations may be distorted by the unconscious presence of the suppressed aspects. In recent theoretical work, this effort has taken the form of retrieving what people have called the republican

13. And, as we will see, it may be that John Rawls's liberalism, seen as an interpretive approach, does not rule out such a recrudescence. See text accompanying notes 45 to 59 .

14. See William Galston, "Pluralism and Social Unity" (1989) 99 Ethics 711 at 724. (Rawls's interpretive approach "leaves no basis for the comparative assessment of regimes").

15. Unfortunately I do not have readily at hand examples of this sort of normative theorizing. If pressed I would suggest with some diffidence that Bernard Williams and Stanley Cavell are exemplars. 
tradition in United States political theory. ${ }^{16}$ By examining some particular difficulties associated with the retrieval of the republican tradition, I hope to illustrate some more general problems with this version of an interpretive normative theory. ${ }^{17}$

For present purposes I will characterize the core element of the republican tradition as the idea of an active citizenry, which participates willingly in the public life of the community because the citizenry finds such participation to be an important element in its definition of the self, though of course not the only such element, and because such a citizenry is the most effective guardian against tyranny emerging either from the state or from other concentrated sources of power. There is substantial evidence that the United States does not today contain a republican citizenry. ${ }^{18}$ What would be the benefits of retrieving the republican tradition? The proponents of a revival of republicanism have reacted to the prevalent liberalism in public life. To them, liberalism appears to promote an aggressive individualism that can accommodate concern for others only with some difficulty, and that always tends to slide into ethical relativism because of its commitment to the proposition that public policy in a liberal state cannot rest on a social judgment that one person's view of the good should prevail over another's contrary view. ${ }^{19}$ In contrast, the proponents of republicanism appear to believe that it embodies an attractive commitment to community and connection among people. To them, public life is one of the activities in which people affirm the values of community and of the essential social nature of human life.

16. See e.g. William Sullivan, Reconstructing Public Philosophy, supra, note 2; Mark Tushnet, Red, White, and Blue: A Critical Analysis of Constitutional Law (Cambridge: Harvard University Press, 1988) at 4-15.

17. For a brief discussion of other difficulties, see Mark Tushnet, supra, note 16 at 133-43.

18. Consider some examples: (1) The rate of participation in the political process is extremely low, suggesting that many people do not find value in participation in the public life of their communities. (Of course, there are structural barriers to participation in voting, such as the unusual system of two-step voting - registration followed by voting. See Richard Cloward \& Frances Fox Piven, Why Americans Don't Vote (New York: Pantheon Books, 1988).) (2) Popular knowledge of the fundamentals of the constitutional system is strikingly low. For example, people do not know that "from each according to his abilities, to each according to his needs" is not a part of the Constitution, or that states have the power to legalize marijuana. See "The American Public's Knowledge of the U.S. Constitution: A Hearst Report" (1987), summarized in PR Newswire, "Hearst Survey on Public and the Constitution," Feb. 16, 1987 (available on NEXIS). (3) The inanity of much of the discussion of the proper role of the Senate in confirming presidential nominees to the Supreme Court suggests that even political elites do not understand how the Constitution works. (4) Concerned that today's citizens are insufficiently sensitive to fundamental norms of civil liberties to be trusted to reenact them as part of a new Constitution, political liberals in the United States express great concern over the possibility of convening a new constitutional convention.

19. Neither of these attributes are inherent in the fundamental concepts of liberalism, but in an interpretive approach what matters is how liberalism is lived and experienced. The point here is that the discourse of liberalism tends to incline people to accepting aggressive individualism and ethical relativism, requiring them to make an effort to overcome those inclinations in ways consistent with their commitments to liberalism. 
As is often recognized, however, there is an underside to the republican community. The republican community can tend to be intolerant and exclusionary. The interpretive liberal stresses the ineradicable pluralism of moral views in modern society. How does a republican community deal with that pluralism? One possibility would be to infuse its citizens with a spirit of toleration. This, however, may be in some tension with the equally important concern in the republican tradition for assuring that the citizenry is guided by concepts of civic virtue. First, toleration of other views may sometimes be purchased at the expense of other desirable attributes of a virtuous citizenry, such as steadfastness in the pursuit of what the citizen regards as the good. Second, it seems likely that all too often the dissent that is the inevitable companion of pluralism will be seen by republican citizens as unvirtuous and therefore deserving condemnation rather than toleration. Thus, if liberalism tends in the direction of an aggressive individualism, republicanism may tend in the direction of intolerant totalitarianism.

Second, the use of the term "citizen" in discussions of republicanism shows that republicanism can be, indeed perhaps must be, exclusionary, in that not everyone can be a citizen of any specific republican polity. The United States Supreme Court made the exclusionary dimensions of the republican tradition clear in a decision that constitutes the clearest reliance on republican ideas in recent years. The case involved a search conducted by United States government agents of a house in Mexico, owned by a Mexican who was under arrest in the United States for drug offenses. ${ }^{20}$ The defendant argued that the search was inconsistent with the limitations placed on government agents by the fourth amendment, either because they had not obtained a warrant or because the conditions of the search made it unreasonable. A liberal might conceptualize the fourth amendment as a limitation on government power: Unless the conditions of the fourth amendment are observed, government agents simply lack authority to act. The Court, in an opinion by Chief Justice Rehnquist, took a different approach. It stressed that the fourth amendment described a "right of the people" to be free of certain actions, and distinguished this language from terms such as "the accused" or "persons" used elsewhere in the Constitution. The Chief Justice concluded that this language "suggests" that the fourth amendment "refers to a class of persons who are part of a national community or who have otherwise developed sufficient connection with this country to be considered part of that conununity." 21

One response within the republican tradition to the problem of ineradicable pluralism is to stress the availability of alternative communities within which people can locate

20. United States v. Verdugo-Urquidez (1990), 110 S.Ct. 1056.

21. The alternative phrasing clearly is designed to handle the problem that under a definition referring solely to "the national community," resident aliens would not be within the protection of the fourth amendment, a conclusion inconsistent with established case law and even more morally repugnant than the Court's. 
themselves. ${ }^{22}$ This response seems inadequate. First, some communities that might be unanimous within themselves may aggressively seek to impose their views on other communities, which may lack the resources to put up an effective defense. ${ }^{23}$ Second, some communities simply do not deserve respect. Indeed, there is a version of the story of the emergence of liberalism that stresses the inadequacies of republican societies for just this reason. That version emphasizes that classical republican societies were able to sustain themselves only by denying what the liberal tradition recognizes as universal human rights. In particular, the conditions for republican citizenship in societies characterized by substantial economic inequality are so stringent that relatively few people qualify as acceptable republican citizens authorized to participate in the public life of the community. Further, sustaining civic virtue in a complex society may lead to unattractive forms of indoctrination both of citizens and of noncitizens.

The interpretive liberal who has drawn on the republican tradition to get some critical leverage on the present state of things has several responses. The first, and most obvious, is that the liberal tradition provides the ground for concepts of universal human rights that limit the intolerance and exclusionary practices of republican polities. Yet, by drawing upon universal concepts, this response abandons the fundamental aspiration of an interpretive approach to normative political theory - the aspiration to interpret particular societies to themselves.

This response suggests a much deeper difficulty that attends all interpretive approaches to liberalism. The difficulty is that there is an inevitable tension between the interpretive striving to identify historically contingent commitments associated with particular communities, and the inescapable fact that one of the commitments of liberal societies since the Enlightenment has been to the identification of universal propositions about individual rights. The historical context of liberalism, that is, is one in which noninterpretive, context-free propositions are believed to be available. One might put it this way: To the extent that an interpretive approach to liberalism is interpretive, it may be impossible to be fully liberal, and to the extent that it is liberal it may be impossible to be fully interpretive. ${ }^{24}$ Admittedly, one might distinguish here between the universal scope of liberalism's claims about human rights and their interpretive grounding in the experience and practices of particular historically situated communities, or between the substantive positions disclosed by an approach to political theory and the form of that approach itself. Yet, the former distinction seems to me unlikely to be helpful, in that the universality of liberalism's human rights claims is likely to come into play only in circumstances where those claims are in some sense projected outward, to communities that do not initially accept the validity of those claims with respect to the regulation of

22.

Concepts of federalism are thus important in the republican tradition, in that they allow people who are unsatisfied with a community's resolution of some dispute to secede. See Mark Tushnet, supra note 16 at 9.

23. This is one version of the story that left republicans might tell about the emergence of a worldwide capitalist system.

24. See William Galston, supra, note 14 at 724-25. 
their own members. ${ }^{25}$ And the latter distinction, between substantive claims and metaapproaches to political theory, seems to me impossible to sustain: We understand both the claims and the approaches only insofar as we understand how they support each other.

A second response to the objections to the republican revival also leads to deeper questions. This response is that the interpretive liberal is not attempting to recreate a republican society of the sort that existed in the past, but is rather attempting to bring back to our attention some republican elements that the prevailing liberalism has led us systematically to overlook. Thus, the reply would be, it is no criticism of this sort of interpretive approach to say that a full scale republican society would not be attractive, because the aim is not to develop such a society, but to infuse republican elements in a liberal society. This reply might then move in one of at least two directions. One would be to treat the retrieval of the republican tradition as simply an effort to create a dialogue over the proper understanding of our own practices, a dialogue that has no theoretical resolution except the one that is actually worked out over the course of discussion. This path leads back to the purely descriptive interpretive approach I discussed earlier, and it thus seems to omit the important normative aspirations that proponents of the retrieval of republicanism plainly have. Perhaps we should distinguish, though, between the normative aspirations those proponents have in their capacities as participants in the effort to infuse republican elements into contemporary political discourse, and their aspirations as political theorists. In the former capacity they are like preachers exhorting us to follow the path that they believe to be best. In the latter capacity, though, they believe that ultimate normative weight is associated not with the particular positions they assert but rather with the ongoing compromises of political discourse as those compromises are worked out over time.

The second path respects the normative aspirations of proponents of republicanism. Much of the literature of republicanism has a powerful romantic streak to it. ${ }^{26}$ Rather than an unending dialogue between liberalism and republicanism, it appears to imagine a resolution in which each limits the excesses of the other: Our republican tradition will place communitarian limits on liberalism's aggressive individualism, while our liberal tradition will place human rights limits on republicanism's intolerance and exclusionary

See Onora O'Neill, "Ethical Reasoning and Ideological Pluralism" (1988) 98 Ethics 705 at 709.("The intermationalist commitments and implications of liberalism are damaged if they are vindicated by reference to an aspect of the Sittlichkeit of a specific tradition. When claims to universal scope are (supposedly) vindicated in terms that could not be made univerally accessible, liberal internationalism is uncomfortably based on intellectual imperialism"). The metaphor of "outwards projection" seems most apt in considering a liberal community's claim that some other member of the system of nation-states is denying human rights, but it should be understood to include problems that arise when a liberal community attempts to impose its notions of human rights on some subcommunity located within its territory, as in the case of the Amish discussed below.

26. Given its status as an interpretive theory, this is hardly surprising: United States society as a whole is infused with a romantic optimism; interpretations of its political practices are likely to be similarly infused. For the basic insight, see C. Vann Woodward, American Counterpoint (Boston: Little, Brown \& Co., 1971). 
practices. The difficulty here is that the romantic optimism seems ungrounded either in theory or in an interpretation of United States history. It seems equally plausible and consistent with the history of the United States that the coexistence of the liberal tradition with the republican one occurs because each accepts, rather than limits, the excesses of the other. Thus, the centralization of economic and political power attendant upon liberalism's individualism coexists with a deep tradition of religious intolerance attendant upon republicanism's communitarianism.

The Supreme Court's jurisprudence of the free exercise clause provides a useful brief example. The Court first confronted questions of free exercise of religion as a result of the central government's efforts to suppress the Mormon practice of polygamy, and the Court held that those efforts were consistent with the free exercise clause, which, its opinion can be read to argue, is an engine of religious homogenization to some lowest common denominator of Christian religiosity. ${ }^{27}$ In 1963 the Court set out on a course allowing it to displace local judgments about religious practices, when it held that a state could not deny unemployment compensation to a person who, because of her sabbatarian religious beliefs, was unable to find a job that would allow her to observe her Sabbath. ${ }^{28}$ But, the Court never seriously followed through on the promise of this decision; it applied it only to essentially identical unemployment cases and to one case involving a respectable religious minority, the Amish. ${ }^{29}$

By 1990 the Court had come to the essentially communitarian position that protection for religious exercise was to be left to the political process. ${ }^{30}$ The Court held that a state need not provide unemployment benefits to members of the Native American Church, who use peyote as part of their religious exercises, if the state makes the use of peyote illegal under all circumstances. The Court recognized, however, that states could exempt members of the Church from their general prohibition on the use of peyote, as a permissible accommodation of their religious beliefs. In this context, then, an individual's right to free exercise of religion is subordinated to a community's decision about what activities are morally appropriate, even when done in the course of a religious observance.

These particular difficulties with the retrieval of republicanism suggest more general problems with the project of gaining normative leverage on a society's practices by directing attention to suppressed or overlooked traditions. Either those traditions generate an ongoing dialogue, in which case the normative aim of the effort is defeated; or they produce normative resolutions at the cost of departing from the interpretive enterprise by appealing to universal solutions (the problem of citizenship and human rights); or they produce normative resolutions at the cost of accepting outcomes unacceptable to the dominant tradition (the problem of intolerance). At present I do not see how this version

Reynolds v. United States (1878), 98 U.S. 145.

Sherbert v. Verner (1963), 374 U.S. 398.

Wisconsin v. Yoder (1972), 406 U.S. 205.

Employment Division, Department of Human Resources v. Smith (1990), 110 S.Ct. 1595. 
of an interpretive approach to normative political theory can fail to generate at least one of these difficulties.

A second interpretive approach accepts the society's practices pretty much as they are, but also draws on those systematic political philosophers whose thought is taken to be central to the development of the society's institutions. The approach then moves back and forth between the actual practices and the systematic theories, using practice to evaluate and modify theory and theory to evaluate and modify practice. A useful recent example is provided by Rogers Smith's examination of Liberalism and American Constitutional Law. ${ }^{31}$ Smith begins by examining the political theories of the Enlightenment, focusing on "the political principles of the more moderate Lockean Enlightenment liberals." ${ }^{\text {"32 }}$ After a systematic (that is, noninterpretive) critique of those principles, Smith turns to a presentation of several issues in constitutional law. Although his presentation here is quite conventional, it has the effect of setting the moderate Lockean principles against the actual development of constitutionalism in the United States, which is offered as an exemplary liberal democratic society in the sense that its institutions are paradigmatic, though revisable, for understanding liberal democracy. The third and most important section of the book returns to political theory, and reads liberal theory in light of liberal experience to derive "the essential goal" of liberalism, which Smith describes as "promoting the capacities of all for reflective self direction, or 'rational liberty'.${ }^{133}$ Smith regards his method as interpretive, criticizing systematic political theories for failing to make it clear "whether their views articulate significant strains in actual governmental discourse," and criticizing systematic analyses of constitutional law for "pay[ing] little attention either to the fundamental dilemmas of America's inherited liberalism or to the alternative visions of it presupposed by the very steps the author may be proposing. ${ }^{.34}$

There are a number of difficulties with this kind of interpretive approach. First, the status of the systematic theories in the enterprise probably must be ambiguous. ${ }^{35}$ On the one hand, the effort cannot be to lay existing practices against, for example, what Locke really means, for that would be simply to use systematic theory as a measure of existing practices and thereby to abandon the effort to interpret those practices. On the other hand, it seems reasonably clear that the interpreter cannot look to how the thought of John Locke was explicitly or implicitly relied on in the course of political development, for that would eliminate the interpreter's ability to use a critical analysis of the theorist's position as a basis for revising existing practices. The dilemma is that the interpreter cannot rely either on "what liberalism really means when systematically analyzed" or on "how

31. My comments in this essay embody some modifications in my previously expressed views of Smith's works in Mark Tushnet, "Conservative Methods, Liberal Results" (1986) 100 Harv. L. Rev. 423. Supra, note 12 at 3.

Ibid. at 5.

Ibid. at 5-6.

Sotiros Barber, "Book Review" (1987) 15 Pol. Theory 657 at 660 identifies the amibiguity in the course of criticizing Smith for failing to follow a systematic rather than interpretive approach. 
liberalism has been expressed in the political history of the United States." Somehow the two perspectives must be combined. The combination, I suspect, is likely to take one of two forms. Smith's work may exemplify one, in which the systematic theories are simply superimposed on the actual practices, leading to the interpreter's essentially ad hoc specification of which practices and what parts of the theories are to be revised in light of each other. The other form reproduces a problem I identified in discussing the retrieval of republicanism. Here the systematic theories and the actual practices coexist in continual dialogue. As before, this does not seem to leave room for the reformist dimension of normative theory.

A second difficulty with an approach that moves back and forth between systematic theory and actual practice is that the description of both elements is sure to be controversial. ${ }^{36}$ The problem is more frequently encountered in systematic theory, where different schools take John Locke or Edmund Burke or the Scottish Enlightenment writers to be the figures whose thought must be evaluated and revised because, the proponents of each claim, each was the central figure in the development of the political institutions of liberalism in the United States. Yet, one will understand the development of those institutions differently, and will construct the interpretive interplay differently, depending on which figure is taken to be central. For example, in recent works, Melvin Urofsky and Herman Belz, one a moderate progressive and the other a moderate conservative, offer competing interpretations of constitutional history because they understand the central political traditions differently. ${ }^{37}$

This difficulty may perhaps be easily seen, because it reproduces in the context of an interpretive approach the general difficulty we have had in developing systematic theories of liberal democracy, as exemplified by the competition between John Rawls and Robert Nozick. An analogous difficulty arises on the other side, where it may be less familiar. The problem there is to characterize or interpret the course of political history. In the field of constitutional law on which Smith draws, for example, there are two basic stories that could be told. The first is that the Supreme Court has been the admittedly inconstant but nonetheless important guardian of fundamental liberties; its work should be seen, in an interpretive approach, as a continuing effort to develop appropriate definitions of fundamental liberties, although particular definitions will inevitably be controversial and may be discarded from time to time. The alternative story is that the Supreme Court has been the more-or-less consistent defender of the privileges of politically dominant groups; its work should be seen, in an interpretive approach, as a continuing effort to develop adequate grounding for the positions preferred by those groups, although particular types of grounding may be controversial when offered and will certainly be discarded as the contours of political power change. Once again, the interpretive interplay between

Also see William Galston, supra, note 14 at 724 (stressing difficulties of interpretation of culture in course of criticizing Rawls's version of interpretive liberalism).

See Alfred Kelley, Winfred Harbison, and Herman Belz, The American Constitution: Its Origins and Development, 6th ed. (New York: Norton, 1983) and Melvin Urofsky, A March of Liberty: A Constitutional History of the United States, (New York: Knopf, 1988). 
systematic theories and actual practice will be quite different depending on which story the interpreter offers. ${ }^{38}$

I am not familiar with enough interpretive efforts akin to Smith's to make a global judgment, so I can conclude here only by expressing my skepticism that this version of interpretive theory will be able to offer more than skillful presentations of possible interpretations of the society's history and therefore my skepticism that it will be able to offer more than obviously contestable suggestions for revision of the society's political institutions. It does not, I suspect, do much more than systematic theory standing alone can do.

A related interpretive strategy uses the central traditions that have received normative approval over the course of the society's history as the basis for revising its present practices. The hope is that this strategy can rely on common agreement as to the central normative traditions and thus avoid controversy both over identifying systematic theorists who are taken to be central to the development of the society's governing theory and over identifying the correct description of the course of the society's political history. Then the interpretive theorist can derive from the central traditions some general animating principles that will be available to criticize existing practices. That is, the principles drawn from the central traditions will be used to purify actual practices. ${ }^{39}$

The work of John Ely is the best example of the use of this strategy in constitutional law. Ely finds in the political traditions of the United States general principles like "prejudice is bad" and "free speech is good," and argues that those general principles can best be understood in light of the nation's commitment to ideas of fair representation in the political process. Ely's approach is undoubtedly appealing, but as his own presentation suggests it may have more severe limitations than its admirers acknowledge. The limitations can be put in general terms: The more accurately one understands the animating principles of the central traditions, the more difficult it is use them to revise existing practices. ${ }^{40}$

Consider, for example, Ely's analysis of problems of discrimination in law. ${ }^{41}$ As Ely understands it, fair representation requires that all interests be taken into account in a system of pluralist bargaining. Yet, the conditions under which a system of pluralist bargaining will ignore or unduly discount the interests of voters belonging to any group are quite restrictive, and, I believe, may well not be satisfied with respect to any

38. I forgo discussion of the obvious complexities that would arise if one pursued the effort by using both stories in an interplay with all the candidates for central status on the side of systematic theory.

39. I draw the term "purification," and some aspects of my understanding of this strategy, from James Fishkin, Reconstructing the Social Contract: Towards a New Liberal Theory (forthcoming).

40. This is not because, as with the prior interpretive approach, there is controversy over what those traditions or even what the animating principles are; the reliance on common agreement in the approach being considered here eliminates, or at least substantially reduces, that difficulty. Rather, the problem arises because the principles themselves map quite closely on to existing practices.

41. This argument draws heavily on Mark Tushnet, supra, note 16 at 94-106. 
significant social group in the contemporary United States. Any group, no matter how small, has votes to offer politicians from other groups seeking to assemble a winning coalition. By carefully identifying issues on which the remainder of the society is closely divided, leaders of such small groups can put their support up for bid, and award the votes to the coalition that needs their support to achieve its goals in exchange for support for the small group's goals.

This process might not occur, however, in two situations. First, the group may be a "pariah" group, that is, one whose addition to a coalition results in a net loss of votes to the coalition. ${ }^{42}$ Earlier in the history of the United States, African-Americans may have been that sort of pariah group, although the picture is complicated by the fact that African-Americans were formally disfranchised for much of the period in which the claim of pariah status has some intuitive appeal. Today, however, it is difficult to identify such pariah groups; the best candidate for a socially significant pariah group is the homosexual community, whose recent political activism suggests that it is no longer such a group, and the most obvious candidate for pariah status, the Unification Church, is not politically significant. Second, the small group may lack effective political leadership. A hypothetical example is a group all of whose members agree on one goal, which is supported by coalition A and opposed by coalition B, but whose members disagree on a second goal, on which coalitions $\mathrm{A}$ and $\mathrm{B}$ also divide. In the absence of effective political leadership, the group may split its support between the two coalitions because some members of the group believe that the second goal is more important than the first one. Unlike the problem of the pariah group, however, this difficulty does not seem to result in anything the central tradition of fair representation would regard as troublesome: Nothing in the tradition says that groups must win on every issue on which they are united, and the tradition certainly recognizes that people differ in the intensity with which they are committed to various goals. ${ }^{43}$

The difficulty I have just identified is not peculiar to Ely's analysis specifically, but is rather a difficulty that attends the general strategy. The reason derives from the focus this strategy places on the society's central traditions. Put simply, it is extremely unlikely, if not impossible, that the actual practices of a society diverge to any significant degree from its central traditions properly understood. Thus, the more accurately the interpreter describes the central traditions, the more unlikely it is that the approach will offer guidance on revising significant actual practices. ${ }^{44}$

42. The term is due to Bruce Ackerman. Bruce Ackerman, "Beyond Carolene Products" (1985) 98 Harv. L. Rev. 713 at 732-33.

43. For a discussion of how similar difficulties arise in an Ely-type analysis of free speech, see Mark Tushnet, supra, note 16 at 89-92.

44. This is not to say, of course, that it offers no guidance at all, but only that it is likely to speak to situations of marginal social significance, as the example of the Unification Church suggests. 
The recent work of John Rawls suggests a second and arguably more promising strategy for purifying existing practices. ${ }^{1}$ Ely and others like him attempt to identify systematic principles that make sense of the society's practices; Rawls uses what might be called a temporal strategy for purifying those practices. The contrast is between an examination of the practices of liberal society as it is now and an examination of the central practices of liberal society over the course of the centuries in which it has become the defining theory of advanced Western society. ${ }^{2}$ Rawls has written of an "overlapping consensus. ${ }^{13}$ Rawls emphasizes the existence of ineradicable disagreement in the modern world over conceptions of the Good. Historically, Rawls argued, liberal society emerged when adherents of competing conceptions came to understand that they could not impose their conceptions on others without permanent warfare. ${ }^{4}$ Thus, people came to understand that, as a matter of prudence, they should refrain from such efforts and should instead tolerate disagreement. Rawls calls a prudential commitment to toleration a modus vivendi, and believes that it is inadequate as a basis on which to rest liberal theory. The overlapping consensus is Rawls's alternative to a modus vivendi. ${ }^{5}$ For Rawls, an overlapping consensus emerges when adherents of competing conceptions of the Good reflect on their conceptions and come to realize that a commitment to toleration can be deduced from their more fundamental commitments. The commitment to toleration, that is, is derived independently by each group, which is committed to it as a matter of principle rather than from prudence, and yet is in an important sense shared across groups.

On this view, Rawls takes the long view of the emergence and consolidation of liberalism. It seems to me that there are a number of difficulties in the approach Rawls

1. I should note that Rawls appears ambiguous on whether his approach is interpretive. For example, in John Rawls, "The Priority of Right and Ideas of the Good" (1988) 17 Phil. \& Pub. Aff. 251, 275, he reiterates the suggestion that he is a Kantian constructivist "working from the fundamental intuitive idea of society as a fair system of cooperation." Even here one sympathetic to interpretive approaches might note that the sources of that "intuitive idea" can be best understood in interpretive terms.

2. See Onora O'Neill, supra, note 25 at 714-15 (stressing how widely the ideals of liberalism are now shared, but noting that this accomplishment may have resulted from unjust forms of imperialism).

3. John Rawls, "The Idea of an Overlapping Consensus" (1987) 7 Ox. J. Legal Stud. 1.

4. John Rawls, "The Domain of the Political and Overlapping Consensus" (1989) 64 N.Y.U. L. Rev. 233 236-39, argues that the diversity of comprehensive views is not a "mere historical contingenc[y]" but is "rooted in the difficulties of exercising our reason under the normal conditions of human life." This restatement of the basis for seeking an overlapping consensus weakens somewhat the interpretive thrust of Rawls's position, but, at least to the extent that the realization of the limits of reason is historically contingent, may not re-transform Rawls back into a noninterpretive liberal. Also see ibid. at 251-52 (approach is not historicist even though "the general facts we have assumed may not appropriately obtain" but "those facts do obtain widely in the modem world").

5. In my view, Michael Perry, Morality, Politics, and Law: A Bicentennial Essay (New York: Oxford University Press, 1988), at 87, erroneously treats the existing consensus in the United States across a rather wide range of issues as illustrating an overlapping consensus rather than a modus vivendi, an error suggested perhaps by Perry's insistence, against Rawls's own statements, that "Rawls' theory is a modus vivendi." Ibid. at 86. Also see Jean Hampton, "Should Political Philosophy Be Done without Metaphysics?" (1989) 99 Ethics 791, 798 (overlapping consensus consists of "principles that, as a matter of fact, everyone in the pluralist society happens to accept, albeit for different reasons"). 
is now offering, ${ }^{50}$ First, although Rawls may properly have identified the central elements or groups in present-day liberal society as it has evolved over the centuries, it seems clear that he has not identified all the groups in the society with commitments to distinctive conceptions of the Good. Some, such as some religious fundamentalists, simply do not find in their principles a derivative commitment to toleration. Second, in some groups there are what I have elsewhere called "identity constitutive" beliefs or elements of one's conception of the Good. ${ }^{51}$ These beliefs, which might involve religion or sexuality, are ones about which adherents would say, "I wouldn't be myself if I confined the scope of my public claims about this belief in the way demanded by principles of toleration or justice. More particularly, I wouldn't be myself if I accepted the claims of others that their rejection of this belief deserves toleration." Identity constitutive beliefs, that is, necessarily universalize, as when certain committed Christians believe that those who deny the divinity of Jesus Christ are so fundamentally in error as to justify severe responses. As a matter of prudence in a society where they find themselves substantially outnumbered, the adherents might refrain from pressing those claims, but then they would not form part of the overlapping consensus, only a modus vivendi. ${ }^{52}$

There are several ways to deal with this objection. First, Rawls has suggested that his approach deals with determining principles of justice in situations where there is pluralism with respect to what he calls "admissible" concepts of the Good. ${ }^{53}$ Concepts of the sort I have mentioned might then be ruled out of bounds for the purposes of Rawls's enterprise. Yet, given the prevalence of such views in advanced Western societies, such a restriction substantially undermines the attractiveness of Rawls's approach conceived as an interpretive one. Second, it might be that in most instances identity constitutive beliefs do not implicate primary goods and are therefore not relevant to the development of principles of justice. Here the difficulty seems to be that such beliefs do appear to have something to do with one item on the list of primary goods, the social bases of respect. Perhaps an appropriate restriction of that item might eliminate the difficulty.

Finally, Rawls might begin to answer this objection by noting that he is concerned with the central elements of liberal society, and that, while there may be groups that have no commitment, or only a prudential one, to toleration, these groups are on the margins of existing liberal society. The response might continue by combining two elements in Rawls's presentation. The first is its extremely long time frame. As Rawls presents it,

I note only in passing that his present position has elicited a standard noninterpretivist liberal response, that liberalism, considered either as a systematic philosophy or in interpretive terms, requires that the principles to which it is committed be accepted as trans-culturally true. See William Galston, supra, note 14; Jeremy Waldron, "Particular Values and Critical Morality" (1989) 77 Cal. L. Rev. 561.

51. Mark Tushnet, "Religion and Theories of Constitutional Interpretation" (1987) 33 Loyola L. Rev. 221 at 238-39.

52. See Jean Hampton, supra, note 49 at 803 .

53. John Rawls, "The Priority of Right and Ideas of the Good," supra, note 45 at 253; also see John Rawls, "The Domain of the Political," supra, note 48 at 243. 
a prudential modus vivendi will produce a principled commitment to justice as people come to understand that their fundamental commitments imply principles that become part of an overlapping consensus. The emphasis Rawls places on the religious wars of three and four centuries ago shows that his evolutionary time frame is rather large. The second element in Rawls's presentation that is relevant here has two components. The concepts of the Good that people have, while more general and comprehensive than merely political views, are not completely general and comprehensive; they have some "looseness" to them. In addition, the virtues of an overlapping consensus are "very great virtues. ${ }^{154}$ Taken together, these propositions suggest that some parts of a general and comprehensive view will be modified as its adherents come to understand that without such a modification it will be impossible to develop an overlapping consensus. ${ }^{55}$ The Rawlsian response would then conclude by suggesting that identity constitutive beliefs are precisely such parts of their adherent's general and comprehensive views. That is why groups with no more than a prudential commitment to toleration are on the margins of modern liberal society, and that is why there is reason to think that over time the remaining backwaters in which such groups are located will be eliminated.

A third general difficulty with Rawls's approach considered in interpretive terms also draws on its time frame. As Rawls presents it, liberalism has resulted in a stable commitment to principles of justice. Consider, however, the possibility that Rawls's time frame, long as it is, is not long enough. He may have mistaken a temporary resting point for a permanent one. Perhaps the development of liberalism over the centuries is really a cyclic process, where moments of stability and toleration supplant and then are supplanted by moments of turmoil and intolerance. Seen in interpretive terms, Rawls's analysis may not support the particular conclusions he draws.

There is, finally, another difficulty with the idea of an overlapping consensus. To use Rawlsian terms, it produces an idea of liberalism that is amazingly thin. Rawls himself offers only the example of toleration, without specifying with any precision what toleration means. ${ }^{56} \mathrm{He}$ also asserts that the principles of justice he developed in $A$ Theory of Justice can be grounded in the concept of an overlapping consensus, ${ }^{57}$ but, given the controversy over, for example, the maximin principle of distributive justice he

Supra, note 47 at $22-23$.

55. For a somewhat different but related point, see Gerald Doppelt, "Is Rawls's Kantian Liberalism Coherent and Defensible?" (1989) 99 Ethics 815, 838 (arguing that critical reflection on substantive issues leads to modification of substantive understandings, whereas I argue that critical reflection on importance of achieving overlapping consensus leads to such modification).

36. Supra, note $\mathbf{4 8}$ at 245 (describing toleration as "a model case of an overlapping consensus").

57. Rawls has said that the general structure of constitutional rights with which we are familiar in the United States and Canada is consistent with his analysis. John Rawls, "The Basic Liberties and Their Priority" supra, note 12. Yet, his argument there does not attempt to show how the specific constitutional rights are derived, as the idea of overlapping consensus requires, from diverse metaphysical positions. Also see Stephen Griffin, "Reconstructing Rawls's Theory of Justice: Developing a Public Values Philosophy of the Constitution" (1987) 62 N.Y.U. L. Rev. 715 at 765 (Rawls "does not undertake" task of "constructing a coherent system of rights"). 
developed there, it seems fair to await a demonstration..$^{58}$ Yet, if the theory we get is so thin, it cannot provide the guidance that we seek from normative interpretive theories. ${ }^{59}$ The strategy of temporal purifying is ingenious, and it is too early to reject it completely, but there is, it seems to me, substantial reason to be skeptical about its prospects.

This concludes my survey of normative interpretive approaches to liberalism. I have argued that none gives precise enough guidance to be useful in resolving contemporary controversies about what liberalism requires or allows, and I have suggested that most of them are unlikely ever to do so, no matter how fully they are developed. It may be unnecessary to add that, of course, communitarian interpretive approaches are almost certain to suffer from the same defects. What this leaves us with, I think, is the prospect that we will be unable to couple normative political theory, whether systematic or interpretive, with efforts to reform existing practices. I take this conclusion to be broadly consistent with the pragmatic approach to political reform offered, for example, by Richard Rorty. ${ }^{60}$ I should stress in conclusion that that pragmatic approach does not purport to rule out in principle efforts to invoke either systematic or interpretive political theories in support of proposed reforms. To the extent that those efforts work to advance the reformist goal, because for example they are effective rhetorical forms in the society in which they are used, they are pragmatically justified. The fact that such efforts falsely claim to derive their prescriptions for reform from systematic or interpretive theories does not in itself make them less useful in promoting reform.

Kurt Baier, "Justice and the Aims of Political Philosophy" (1989) 99 Ethics 771 at 775-78, argues for an even thinner conception, which he calls "constitutional" and which involves the existence of consensus on procedures for the determination of substantive matters. I believe that Baier overestimates the degree to which such a consensus exists at a level helpful to the resolution of the substantive controversies; only insofar as people do not understand how the procedures work to skew results are they committed to the procedures, or so I believe.

See Michael Moore, "Sandelian Antiliberalism" (1989) 77 Cal. L. Rev. 539 at 547 ("agreements run out in the details that they can govern. It is easy enough to agree that everyone has a right to free speech, harder to secure agreement that that means the Nazis can march in Skokie.... [N]o amount of purely liberal agreement about rights at a high level of abstraction will serve the minimalist ends of social cooperation and harmony").

See e.g. Richard Rorty, "Unger, Castoriadis, and the Romance of a National Future" (1988) 82 Nw. U.L. Rev. 335. 